\title{
Use of downloads from the Journal
}

The British Journal of General Practice holds a special place in the scientific literature of medicine, as it was the first GP peer-reviewed journal in the world to be accepted by the scientific community when it was first included in Index Medicus in 1961. At that time the Journal was called the Journal of the College of General Practitioners.

This important achievement marked the emergence of general practice/family medicine as a discipline in its own right and was due to the Foundation Editor, Dr RMS McConaghey, and his Editorial Board. No other college of GPs/family physicians in the English-speaking world at that time went down the difficult road of seeking and publishing peer-reviewed other family medicine journals mostly published review articles.

For years former Editors dreamed of electronic publication, now achieved under the present Editor, and this left open the question of access to all the previously published articles. Hopes of digitising them were too expensive for the College. Then along came the Wellcome Trust, the biggest charity in Europe, with its policy of enhancing the public understanding of science. This Trust generously decided to original articles from general practice. The

digitise the back issues of all the UK's leading medical journals. The title, the British Journal of General Practice had been taken by the then Editor as a subtitle in 1976 and was adopted as the main title for the Journal in 1990. This Journal was selected for general practice for the digitisation project:

(www.rcgp.org.uk/publications/bjgp/login. aspx - click on Archive).

\section{USE OF DOWNLOADS}

The number of downloads from the Journal going back to 1953 is striking. In the 12 months ending 31 March 2009, 715011 full text articles were downloaded from the PubMed Central site (Table 1). This covered all text between 1953 and March 2008; that is, ever since this publication began in the form of a Research Newsletter for members.

This very high use (M Walport, personal communication, 2009) means that, according to the Wellcome Trust data, since there were 15009 articles at the midpoint of this year (progressively increasing), the average article was being downloaded 47.6 times. Many articles have very much higher figures.

Put another way, journal articles are being downloaded at the rate of 1959 a day. By March 2009, this Journal was

Table 1. BJGP archive $^{a}$ statistics on use: April 2008-March 2009.

\begin{tabular}{lccccc} 
Date & $\begin{array}{c}\text { Articles } \\
\text { available }\end{array}$ & $\begin{array}{c}\text { Total items } \\
\text { available }\end{array}$ & Downloads $^{\mathrm{b}}$ & $\begin{array}{c}\text { Other pages } \\
\text { retrieved }\end{array}$ & $\begin{array}{c}\text { Total } \\
\text { use }\end{array}$ \\
\hline March 2009 & 16274 & 18521 & 80475 & 60693 & 141168 \\
\hline February 2009 & 16246 & 18492 & 60852 & 46996 & 107848 \\
\hline January 2009 & 16064 & 18247 & 58890 & 43949 & 102839 \\
\hline December 2008 & 15916 & 18059 & 49551 & 38322 & 87873 \\
\hline November 2008 & 15886 & 18029 & 66174 & 48255 & 114429 \\
\hline October 2008 & 15793 & 17912 & 62875 & 49071 & 111946 \\
\hline September 2008 & 15009 & 16822 & 54395 & 49399 & 103794 \\
\hline August 2008 & 14986 & 16797 & 45638 & 41670 & 87308 \\
\hline July 2008 & 14955 & 16766 & 49047 & 38552 & 87599 \\
\hline June 2008 & 14926 & 16735 & 58824 & 42483 & 101307 \\
\hline May 2008 & 14896 & 16705 & 62937 & 44130 & 107067 \\
\hline April 2008 & 14857 & 16666 & 65353 & 47261 & 112614 \\
\hline
\end{tabular}

${ }^{a}$ Archive at PubMed Central: www.rcgp.org.uk/publications/bjgp/login.aspx - click on Archive.

${ }^{\mathrm{b}}$ Full downloads include PDF and HTML formats combined. receiving 81.6 downloads per hour, from 149 different countries/territories. In $2008 / 2009$ someone, somewhere in the world, downloaded an article from this Journal at the rate of one every 44.1 seconds, day and night.

Furthermore, these are early days. Many will not yet know of this relatively new facility. Indeed the Heritage Committee has only just written to all the Faculties of the College to inform them. In addition, computers are becoming progressively cheaper. Search engines, like Google, are now also identifying articles in the Journal. While for now, the UK is the leading country of use, soon millions in Asia alone will have access and international use is likely to rise considerably (Figure 1).

\section{IMPLICATIONS}

There is much to celebrate; for example, over 2.5 million hits on this Journal's archive between May 2006 and January 2009. General practice literature has never had the respect and understanding it deserves and many fundamental discoveries and insights are included in these older articles. They are an academic goldmine for medical historians.

The Journal of the Royal College of General Practitioners, as it became in 1967, held the world lead for general practice in academic standing for decades but was gradually overhauled by North American journals like the Journal of Family Practice. However it remains, measured on impact factors, one of the highest ranked general practice journals in the world, and the highest in Europe. Current issues are going online, in addition to the archive of older articles, and can be accessed worldwide at: www.rcgp.org.uk/bjgp.

New thoughts are emerging about the value of full downloads as they are now so much more easily counted and do form verifiable evidence of relevance and use.

Already, Perneger, ${ }^{1}$ in a prospective study, has shown a relation between 'hit counts' and subsequent citations. It is not inconceivable that full downloads or even hits may come to be incorporated in new formulae for impact factors in the future. 


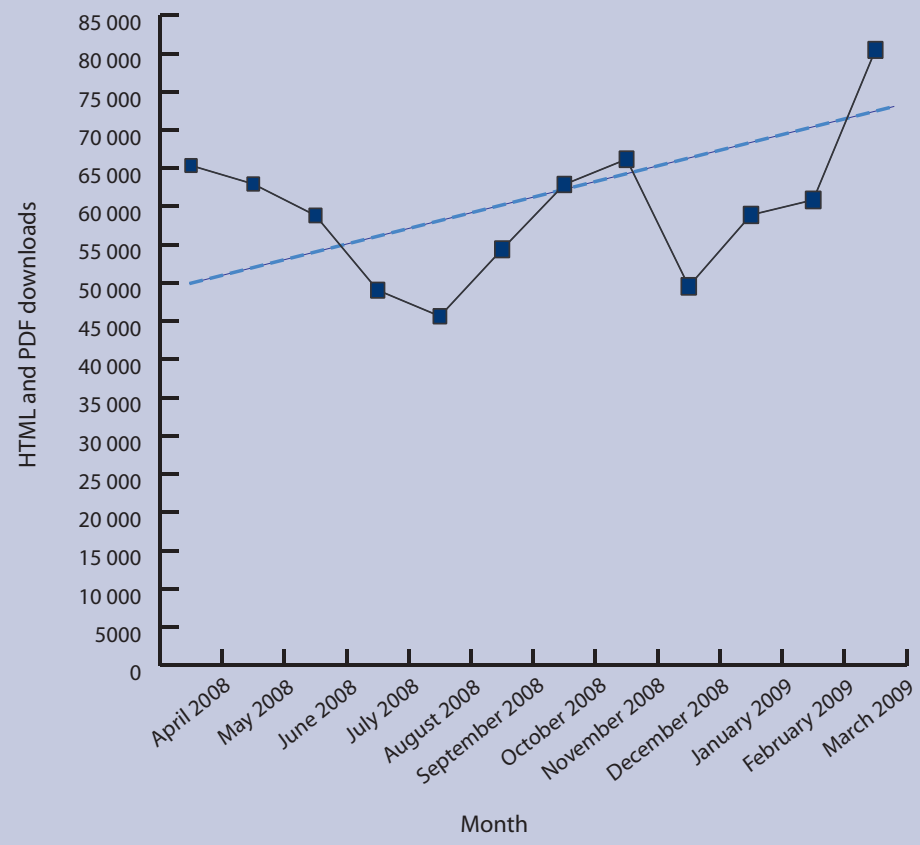

Figure 1. Number of full downloads, HTML and pdf combined, per month.

Meanwhile, every GP, every historian, and every social scientist around the world with internet access can read and/or download these articles from home or practice at any time of the day or night. For example, any reader wanting to look at or download McConaghey's article, from $1972,{ }^{2}$ can now do so at their personal computer and at their convenience. This facility is likely to lead to even more downloads in the future.

There are implications for academic general practice. As so many downloads are occurring from just this one journal, how soon can the other leading journals of general practice/family medicine be digitised? And who will pay?

Meanwhile, the College, and indeed the whole of general practice/family medicine, owes the Wellcome Trust, its Trustees, and Director Sir Mark Walport, a great debt. The Trust is also pleased with what it has called these 'splendid statistics'.

This was a visionary project doing much for the discipline of general practice, for medical science, and for the standing of the UK.

There are, of course, among any large group of people, some who live entirely in the present and think like Henry Ford that:
'We want to live in the present, and the only history that is worth a tinker's dam is the history we make today'. ${ }^{3}$

There are fewer such people among GPs than other groups for two reasons. First, the College of General Practitioners would not have been founded in the 1950s if its then leaders had not been acutely aware of the history of medicine in the 1840 s. $^{2}$ When the attempt was made to strangle the College at birth, ${ }^{4}$ they decided to found the College in secret to circumvent that threat.

Secondly, the longer GPs are in practice, the more they come to realise how many of the problems they meet in the consulting room have links to the patient's past or family history.

These remarkable download figures demonstrate elegantly, and also quantify, some of the value of the College's heritage and its continuing relevance to today's doctors in the UK and around the world.

\section{Denis Pereira Gray,}

Consultant at the St Leonard's Research General Practice Exeter; Chairman of the Heritage Committee, Royal College of General Practitioners; and former Honorary Editor of the Journal of the Royal College of General Practitioners.

\section{Provenance}

Freely submitted; peer reviewed.

\section{Acknowledgements}

Mr Robert Kiley, Wellcome Trust London, for help with data analysis.

\section{REFERENCES}

1. Perneger TV. Relation between online "hit counts" and subsequent citations: prospective study of research papers in the BMJ. BMJ 2004; 329: 546-551. http://www.pubmedcentral.nih.gov/picrender.fcgi?art $\mathrm{id}=516105 \&$ blobtype $=$ pdf (accessed 5 May 2009).

2. McConaghey RMS. Proposals to found a Royal College of General Practitioners in the nineteenth century. J R Coll Gen Pract 1972; 22: 775-788. http://www.pubmedcentral.nih.gov/picrender.fcgi?art $\mathrm{id}=2157030 \&$ blobtype $=$ pdf (accessed 5 May 2009)

3. Ford H. Interview. Chicago Tribune 1916; 25 May.

4. Brain R. Letter (on behalf of the then three English Medical Royal Colleges). In: Pereira Gray D. The history of the first forty years of the Royal College of General Practitioners. London: Atalink, 1992: 28.

DOI: 10.3399/bjgp09X420914

\section{ADDRESS FOR CORRESPONDENCE}

\section{Sir Denis Pereira Gray}

9 Marlborough Road

Exeter, EX2 4TJ.

E-mail: denis.pereiragray@btinternet.com 